\title{
PENGARUH STRATEGI POSITIONING TERHADAP KEPUTUSAN PEMBELIAN PRODUK JASA ASURANSI PADAPT. JIWASRAYA DI TANGERANG
}

\author{
Abdul Karim Butar-butar \\ Universitas Muhammadiyah Tangerang \\ abdulkarimbutarbutar@gmail.com
}

Keyword
Positioning strategy, decision

Purchase

\section{Abstract}

The purpose of this research is to identify and analize the effect of positioning strategy to product, price and service on the decision purchase costumer at PT. Jiwasraya in Tangerang. Population is customer of PT. Jiwasraya in Tangerang. The sampling technique used purposive sampling method that is sampled because someone happened to be in this research at PT. Jiwasraya in Tangerang. This research used multiple linier regression analysis with sigifikan alpha $5 \%$. The result showed that product, price and service have significant effect to the decision purchase customer at PT. Jiwasraya in Tangerang. The partial test showed that product and price have positive and significant to the decision purchase costumer at PT. Jiwasraya in Tangerang. Service have positive and not significant to the decision purchase costumer at PT. Jiwasraya in Tangerang. Through testing the adjusted coefficient of determination (Adjusted $R$ square) obtained a value of 0,611 or $61,1 \%$ the decision purchase customer decision as the dependent variable can be explained by the product, price, and service as independent variables. While the remaining $38,9 \%$ can be explained by other variables not examined in this study.

\section{PENDAHULUAN}

\section{Latar Belakang Masalah}

Pemasaran merupakan kegiatan yang paling utama dalam sebuah perusahaan, oleh karena itu setiap perusahaan dituntut untuk membuat strategi untuk merebut peluang pasar yang ada dengan melakukan bauran pemasaran. Dengan demikian bauran pemasaran sebagai alat pemasar dalam melakukan aktivitas pemasaran dapat digunakan untuk membantu perusahaan dalam mengenalkan produknya kepada masyarakat, sehingga mereka mengenal dan mau mencobanya (Dharmesta dan Handoko, 2008).

Posisi (positioning) adalah proses membangun dan mempertahankan tempat (image) tertentu di pasar (benak konsumen) tentang apa-apa yang ditawarkan organisasi dan/ atau individu. Menggambarkan proses ini dimana perusahaan yang paling sukses adalah mereka yang mampu mempertahan image untuk mencapai posisi tertentu yang berbeda dari posisi pesaingnya. Mereka membedakan dirinya dengan mengubah karakterstik umum (mempunyai karakteristik tertentu yang berbeda atau unik) sehingga perbedaan itu menjadi posisi perusahaan di pasar semakin meningkat (Engel et al., 2003).

Pendekatan manfaat memang agak unik dan karena itulah sering digunakan sebagai basis untuk merumuskan pernyataan positioning. Dalam strategi positioning itu, manfaat yang sangat istimewa menurut konsumen dapat ditonjolkan atau dijadikan jendela untuk membangun citra produk secara keseluruhan (Kasali, 2008).

Untuk mengetahui nilai atau manfaat yang dianggap penting oleh konsumen bukanlah hal yang mudah, mengingat produk atau jasa yang beredar di pasar sangat beragam. Konsumen menyikapi informasi mengenai produk atau jasa tersebut sesuai dengan persepsi masing-masing. 
Persepsi itulah yang akan mempengaruhi mereka dalam pengambilan keputusan pembelian. Pengambilan keputusan oleh konsumen untuk melakukan pembelian suatu produk jasa diawali oleh adanya kesadaran atas pemenuhan kebutuhan dan keinginan yang kemudian diikuti dengan pencarian informasi (Nurdiana, 2007).

Konsumen memutuskan membeli dan mengkonsumsi produk bukan sekedar karena nilai fungsi awalnya, tetapi juga karena nilai sosialnya. Keputusan pembelian merupakan perilaku yang dilakukan oleh individu-individu yang berbeda. Individu adalah konsumen yang potensial untuk membeli suatu produk tertentu yang ditawarkan oleh perusahaan atau ditemukan di pasar (Durianto, 20 I I).

Persepsi konsumen terhadap jasa atau merek bersifat relatif terhadap struktur persaingan. Begitu keadaan pasar berubah, begitu perusahaan pemimpin pasar jatuh, atau begitu pendatang baru berhasil menguasai pasar tempat tertentu, maka positioning merupakan strategi yang harus terus dievaluasi, dikembangkan dan dipelihara (Kasali, 2008).

PT. Asuransi Jiwasraya adalah Badan Usaha Milik Negara Indonesia yang bergerak di sektor asuransi. PT. Jiwasraya melakukan penjualan baik secara perseorangan atau kelompok. Namun, di dalam melakukan penjualan tersebut dirasakan kurang efektif apalagi penjualan dilakukan secara perseorangan tentu hal tersebut dapat menjalankan penjualan secara lambat dimana jumlah pemakai jasa sedikit.

Jasa pelayanan asuransi jiwa semakin banyak ditawarkan kepada konsumen mengakibatkan calon pembeli jasa akan bingung memilih asuransi jasa yang ditawarkan. Calon pembeli cenderung akan memilih asuransi jiwa yang telah diketahui lebih berkualitas dan bermanfaat, lebih murah iurannya dan cepat dalam mengeluarkan biaya klaim.

PT. Jiwasraya berjuang keras untuk mempertahankan image asuransi jiwa khususnya dalam memberikan klaim kepada nasabah yang mengklaim asuransinya. Dengan adanya kerjasama yang diperoleh pada saat awal konsumen memutuskan untuk memilih asuransi PT. Jiwasraya maka haruslah sesuai kesepakatan tersebut dengan apa yang diterimanya saat pengklaiman asuransi tersebut.

Berdasarkan uraian di atas peneliti tertarik untuk melakukan penelitian dengan judul "Pengaruh Strategi Positioning terhadap Keputusan Pembelian Produk Jasa Asuransi pada PT. Jiwasraya Tangerang".

\section{Rumusan Masalah}

Berdasarkan uraian pada latar belakang di atas, maka permasalahan dalam penelitian ini dapat dirumuskan sebagai berikut:

I. Apakah produk berpengaruh positif terhadap keputusan pembelian pada PT. Jiwasraya Tangerang?

2. Apakah harga berpengaruh positif terhadap keputusan pembelian pada PT. Jiwasraya Tangerang?

3. Apakah pelayanan berpengaruh positif terhadap keputusan pembelian pada PT. Jiwasraya Tangerang?

4. Apakah produk, harga dan pelayanan berpengaruh positif terhadap keputusan pembelian pada PT. Jiwasraya Tangerang?

\section{TINJAUAN PUSTAKA}

\section{Strategi Positioning}

Definisi Positioning menurut Para Ahli sebagai berikut:

Menurut Hasan (2008) :"Positioning adalah penempatan sebuah merek di bagian pasar di mana merek tersebut akan mendapatkan sambutan positif dibanding-kan dengan produkproduk saingannnya".

Menurut Philip Kotler yang dialih Bahasakan oleh Jaka Wasana (2008) menyatakan bahwa :"Penempatan atau positioning adalah tindakan merancang produk, dan bauran pemasaran agar dapat tercipta kesan tertentu diingatan konsumen ".

Menurut Soegoto (2009) :"Positioning adalah cara membangun citra atau identitas di benak konsumen untuk produk, merek, atau lembaga tertentu dengan membangun persepsi relatif suatu produk terhadap produk lain".

Menurut Utami (2010) :"Penentuan posisi adalah membentuk citra perusahaan".

Strategi positioning merupakan salah satu dari tiga strategi pemasaran yang terdiri dari segmenting, targeting dan positioning. Strategi positioning adalah sebuah strategi yang berusaha menciptakan diferensiasi yang unik dalam benak konsumen sehingga terbentuk citra (image) merek atau produk yang lebih unggul dibandingkan merek atau produk pesaing. Elemen pokok yang terdapat pada positioning mencakup what you stand for, what you are, dan how you would like customers to evaluate you.

Menurut Soegoto (2009): Kemampuan untuk mengidentifikasi peluang positioning merupakan ujian yang berat bagi seorang pemasar. Keberhasilan satu positioning biasanya berakar pada berapa lama produk tersebut mempunyai keunggulan bersaing. 
Efektifitas strategi positioning dipengaruhi oleh empat faktor yaitu target pasar, daur hidup produk, strategi unti bisnis dan bauran pemasaran Menurut Hasan (2008):

I. Target Pasar, strategi positioning akan diawali dari target pasar (mengestimilasi respon pasar, merumuskan alternatif strategi), memperhitungkan persaingan, kinerja (penjualan, pangsa pasar, profit) serta tersediannya sumber daya.

2. Daur Hidup Produk: masing-masing tahapan memiliki kondisi berbeda, memerlukan strategi positioning pemasaran yang berbeda.

3. Strategi Unit Bisnis: Strategi Positioning akan terikat dengan strategi unit bisnis.

4. Program pemasaran: Persepsi yang dibentuk melalui program marketing mix, terutama program komunikasi pemasaran dan perbedaan produk.

\section{Keputusan Pembelian}

Menurut Kotler (2006), keputusan pembelian adalah tindakan dari konsumen untuk mau membeli atau tidak terhadap produk. Dari berbagai faktor yang mempengaruhi konsumen dalam melakukan pembelian suatu produk atau jasa, biasanya konsumen selalu mempertimbangkan kualitas, harga dan produk sudah yang sudah dikenal oleh masyarakat.

Pengertian lain tentang Keputusan pembelian menurut Schiffman dan Kanuk (2007) adalah "the selection of an option from two or alternative choice". Dapat diartikan, keputusan pembelian adalah suatu keputusan seseorang dimana dia memilih salah satu dari beberapa alternatif pilihan yang ada.

\section{Kerangka Konseptual}

Strategi positioning merupakan strategi yang berusaha menciptakan diferensiasi yang unik dalam benak pelanggan sasaran, sehingga terbentuk citra (image) produk yang lebih unggul dibandingkan pesaing (Hasan, 2008).

Menurut Lovelock (2009) dimensi

Positioning adalah: Product, Price), Services

I. Positioning menurut product (produk): Produk ini terjadi apabila suatu perusahaan memposisikan diri menurut atribut, seperti ukuran dan lama keberadaannya

2. Positioning menurut price (harga): Produk diposisikan sebagai produk yang menawarkan produk terbaik.

3. Positioning menurut service (pelayanan): Positioning yang meliputi unsur unsur lingkungan fisik, yang meliputi fasilitas, kenyamanan, serta pelayanan personal karyawan.
Menurut Kotler (2006), keputusan pembelian adalah tindakan dari konsumen untuk mau membeli atau tidak terhadap produk. Dari berbagai faktor yang mempengaruhi konsumen dalam melakukan pembelian suatu produk atau jasa, biasanya konsumen selalu mempertimbangkan harga, pelayanan dan produk sudah yang sudah dikenal oleh masyarakat sebelum konsumen memutuskan untuk membeli.

Strategi positioning yang dilakukan suatu perusahaan dengan baik dapat menciptakan citra produk yang baik dalam benak konsumen. Hal tersebut pada akhirnya akan mampu mendorong seorang konsumen memutuskan untuk membeli dan menggunakan produk perusahaan tersebut. Dengan demikian maka dapat meningkatkan volume pembelian produk perusahaan.

Berdasarkan landasan teori dan masalaah penelitian, maka peneliti mengembangkan kerangka konsep penelitian yang akan diuji secara simultan dan parsial sebagai berikut:

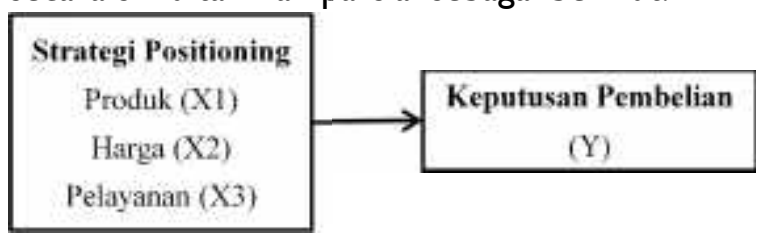

\section{Gambar I. Kerangka Konseptual}

\section{Hipotesis}

Menurut Sugiyono (2006), hipotesis merupakan jawaban sementara terhadap rumusan masalah penelitian, di mana rumusan masalah penelitian telah dinyatakan dalam bentuk pertanyaan. Berdasarkan umusan masalah dan kerangka konseptual maka hipotesis dalam penelitian ini yaitu:

$\mathrm{HI}$ : Terdapat pengaruh positif antara produk terhadap keputusan pembelian pada PT. Jiwasraya Tangerang.

H2: Terdapat pengaruh positif antara harga terhadap keputusan pembelian pada PT. Jiwasraya Tangerang.

H3: Terdapat pengaruh positif antara pelayanan terhadap keputusan pembelian pada PT. Jiwasraya Tangerang.

H4: Terdapat pengaruh positif antara produk, harga dan pelayanan terhadap keputusan pembelian pada PT. Jiwasraya Tangerang.

\section{METODE PENELITIAN}

\section{Jenis Penelitian}

Jenis penelitian ini adalah explanatory research, yaitu penelitian yang bertujuan untuk menjelaskan kedudukan yang diteliti serta 
hubungan dan pengaruh antara satu dengan lain (Sugiyono, 2009).

\section{Variabel Penelitian}

Variabel penelitian adalah hal-hal yang dapat membedakan atau membawa variasi pada nilai (Sekaran, 200). Penelitian ini menggunakan dua variabel yaitu variabel independen dan variabel dependen.

I. Variabel dependen (variabel terikat)

Dalam penelitian ini yang menjadi variabel dependen adalah keprutudan pembelian (Y).

2. Variabel independen (variabel bebas)

Dalam penelitian ini yang menjadi variabelvariabel independen adalah hubungan produk $(X \mathrm{I})$, Harga $\left(\mathrm{X}_{2}\right)$ dan Pelayanan $\left(\mathrm{X}_{3}\right)$

\section{Definisi Operasional}

Definisi operasional merupakan suatu defenisi yang diberikan pada suatu variabel dengan memberikan arti dan membenarkan kegiatan atau suatu operasional yang diperlukan untuk mengukur variabel tersebut untuk mempermudah pengukuran variabel penelitian. Definisi operasional dari penelitian ini adalah strategi positioning yang terdiri dari produk, harga dan pelayanan, serta keputusan pembelian yang diukur dengan indikator-indikator yang dapat dilihat pada Tabel I di bawah ini:

\section{Tabel I. Definisi Operasional Variabel}

\begin{tabular}{|c|c|c|c|}
\hline Variahsl & Defeniai Operasional & Indikstur & $\begin{array}{l}\text { Skath } \\
\text { Clkw }\end{array}$ \\
\hline Produk $\left(X_{0}\right)$ & 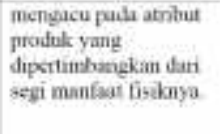 & $\begin{array}{l}\text { 1. Spesifikas produk } \\
\text { 2. Variasi produlk } \\
\text { 1. Manfat produk } \\
\text { 4. Kemudahan menutakes } \\
\text { produk }\end{array}$ & Laked \\
\hline Harga $(\mathrm{X})$ & 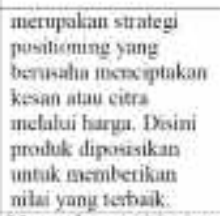 & $\begin{array}{l}\text { 1. Harga vaug kosapetitif } \\
\text { 2. Harga yang ictjanglan } \\
\text { 3. Harga sesuai kualitas }\end{array}$ & Likert \\
\hline Pelayman $\left(X_{0}\right)$ & 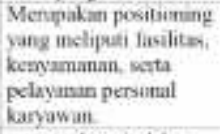 & 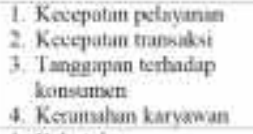 & Taker \\
\hline $\begin{array}{l}\text { Keyutusan } \\
\text { Pemhelian (Y) }\end{array}$ & 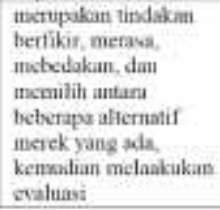 & $\begin{array}{l}\text { 1. Katbituban } \\
\text { 2. Rekivnendas } \\
\text { 3. Kegakinam menbeli }\end{array}$ & Eabent \\
\hline
\end{tabular}

Sumber : Data diolah (2017)

\section{Populasi dan Sampel}

Populasi adalah wilayah generalisasi yang terdiri atas objek atau subjek yang mempunyai kualitas dan karakteristik tertentu yang ditetapkan oleh peneliti untuk dipelajari dan kemudian ditarik kesimpulannya (Sugiyono,
2009). Populasi dalam penelitian ini adalah seluruh pemakai produk jasa asuransi jiwa pada PT. Jiwasraya Tangerang yaitu sebanyak II72 orang.

Jumlah sampel didapatkan dengan menggunakan rumus Slovin sebagai berikut:

$$
n=\frac{N}{1+N(\epsilon)^{2}}=\frac{1172}{1-11720.1)^{2}}=\frac{1172}{1272}=52,14
$$

Dibulatkan menjadi 93 sampel.

Keterangan :

$n \quad$ : ukuran sampel

$N$ : ukuran populasi

e : kemungkinan ketidaktelitian karena kesalahan pengambilan sampel yang dapat ditolerir $(e=10 \%)$.

Dari hasil perhitungan sampel diatas maka jumlah sampel dalam penelitian ini sebanyak 93 responden.

Teknik pengambilan sampel yang digunakan dalam penelitian ini adalah melalui pendekatan accidental sampling

\section{Analisis Regresi Linear Berganda}

Secara umum analisis ini digunakan untuk meneliti pengaruh dari beberapa variabel independen (variabel $X$ ) terhadap variabel dependen (variabel Y) (Ghozali, 2005). Pada regresi berganda variabel independen (variabel $X)$ yang diperhitungkan pengaruhnya terhadap variabel dependen (variabel Y), jumlahnya lebih dari satu. Dalam penelitian ini, variabel independen adalah produk $\left(X_{1}\right)$, harga $\left(X_{2}\right)$ dan pelayanan $\left(X_{3}\right)$ sedangkan variabel dependen adalah keputusan pembelian (Y) sehingga persamaan regresi bergandanya adalah:

$Y=a+b_{1} X_{1}+b_{2} X_{2}+b_{3} X_{3}+e$

Dimana:

Y : Keputusan Pembelian

a : Konstanta

$b_{1}, b_{2}, b_{3}:$ Koefisien masing-masing faktor

$X_{1} \quad$ : Produk

$X_{2}$ : Harga

$\mathrm{X}_{3}$ : Pelayanan

\section{Pengujian Hipotesis}

Untuk mengetahui pengaruh masing-masing variabel bebas pada variabel terikat perlu dilakukan pengujian signifikansi dari masingmasing koefisien regresi yaitu dengan menggunakan $U j i \mathrm{t}$ dan uji $\mathrm{F}$.

Uji t digunakan untuk mengetahui pengaruh variabel independen secara parsial terhadap variabel dependen, apakah pengaruhnya signifikan atau tidak (Priyatno, 2009).

Uji $F$ pada dasarnya menunjukan apakah semua variabel independen atau bebas yang 
dimasukan dalam model mempunyai pengaruh secara bersama-sama terhadap variabel dependen atau terikat (Priyatno, 2009).

\section{HASIL PENELITIAN DAN PEMBAHASAN}

\section{Hasil Penelitian}

\section{Analisis Regresi Berganda}

Berikut hasil perhitungan regresi linier berganda antara variabel Produk $\left(X_{1}\right)$, Harga $\left(X_{2}\right)$ dan Pelayanan $\left(X_{2}\right)$ terhadap Keputusan Pembelian (Y). Melalui proses perhitungan SPSS dapat diperoleh hasil sebagai berikut:

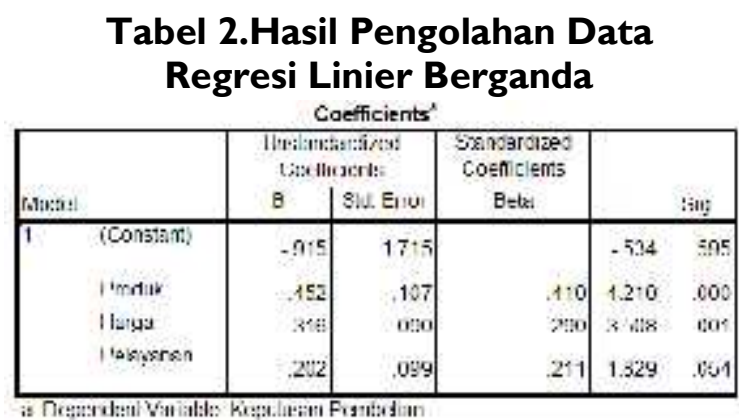

Sumber : Data primer diolah, 2018

Sehingga dari persamaan rumus regresi linier berganda dapat diperoleh hasil sebagai berikut:

$Y=-0,915+0,452 X_{1}+0,316 X_{2}+0,202 X_{3}$

Hasil persamaan regresi berganda tersebut diatas memberikan pengertian bahwa:

a. Nilai konstanta $-0,915$ mempunyai arti bahwa apabila variabel-variabel bebas yaitu produk, harga dan pelayanan itu konstan atau tidak berubah maka perubahan keputusan pembelian negatif.

b. $\quad b_{।}$ (nilai koefisien regresi $X_{1}$ ) 0,452 mempunyai arti bahwa jika produk lebih ditingkatkan sedangkan variabel lain adalah tetap (konstan) maka keputusan pembelian juga akan meningkat.

c. $b_{2}$ (nilai koefisien regresi $X_{2}$ ) 0,316 mempunyai arti bahwa harga lebih ditingkatkan sedangkan variabel lain adalah tetap (konstan) maka keputusan pembelian juga akan meningkat.

d. $\quad b_{3}$ (nilai koefisien regresi $X_{3}$ ) 0,202 mempunyai arti bahwa pelayanan lebih ditingkatkan sedangkan variabel lain adalah tetap (konstan) maka keputusan pembelian juga akan meningkat.

\section{Analisis Koefisien Determinasi}

Koefisien determinasi digunakan untuk mengetahui seberapa besar variabilitas variabel independen dalam menjelaskan variabel dependen yang ditunjukkan oleh nilai Adjusted $R$ square $\left(R^{2}\right)$ yaitu sebesar $0,6 \mathrm{II}$ artinya variabilitas variabel produk, harga dan pelayanan hanya mampu menjelaskan keputusan pembelian $61,1 \%$; sedangkan sisanya sebesar $38,9 \%$ dipengaruhi oleh variabilitas variabel lain yang tidak diteliti dalam penelitian ini. Hasil Output SPSS dari Koefisien determinasi dapat dilihat pada tabel dibawah ini.

Tabel 3.Koefisien Determinasi Model Summary

\begin{tabular}{|c|c|c|c|c|}
\hline Mnde: & IR & REscuale & $\begin{array}{l}\text { Adjustec R } \\
\text { Suvale }\end{array}$ & $\begin{array}{c}\text { Sto. Lror of the } \\
\text { Esinntule }\end{array}$ \\
\hline 1 & $70 n^{2}$ & 824 & 811 & 1,15628 \\
\hline
\end{tabular}

Sumber: Data primer diolah, 2018

\section{Pengujian Hipotesis}

Pengujian hipotesis dilakukan untuk mengetahui apakah persamaan regresi yang diperoleh dapat dipertanggung jawabkan atau tidak. Bila hasil analisis nanti menunjukkan bahwa persamaan regresi yang bersangkutan adalah signifikan atau dapat dipertanggungjawabkan, maka persamaan regresi tersebut dapat digunakan untuk meramalkan variabel $Y$ dan sekaligus untuk membuktikan hipotesis yang diajukan.

I. Pengujian Hipotesis Secara Parsial (Uji t) Uji t digunakan untuk mengetahui pengaruh produk $\left(X_{1}\right)$, harga $\left(X_{2}\right)$ dan pelayanan $\left(X_{3}\right)$ secara parsial terhadap keputusan pembelian (Y).

\section{Tabel 4.Uji Hipotesis Secara Parsial} (Uji t)

\begin{tabular}{|c|c|c|c|c|c|c|}
\hline \multirow{2}{*}{\multicolumn{2}{|c|}{ Als:t:a: }} & \multicolumn{2}{|c|}{ 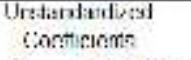 } & \multirow{2}{*}{$\begin{array}{l}\text { Stancarized } \\
\text { Coufficituls } \\
\text { Belsi }\end{array}$} & \multirow[b]{2}{*}{1} & \multirow[b]{2}{*}{ si:g } \\
\hline & & B & Sul. Env & & & \\
\hline 1 & (Constenti & -915 & 171.5 & & -.534 & $\operatorname{sen}$ \\
\hline & I rrodis & .152 & .07 & .110 & $4.2 \div 0$ & .000 \\
\hline & I letty:s & $311 i$ & $19: 0$ & 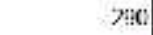 & $360 x$ & Ww1 \\
\hline & I'efizyaran & & vSg & 205 & $5.82 \%$ & . WEA \\
\hline
\end{tabular}

Sumber : Data primer diolah, 2018

Hasil pengujian hipotesis menunjukkan bahwa nilai $t$ hitung untuk produk adalah 4,2 10 dengan signifikansinya sebesar 0,000 ; sedangkan pada taraf signifikansi sebesar 0,05 dengan degree of freedom (df) sebesar $=89$ diperoleh nilai $t$ tabel sebesar 1,987 sehingga nilai $t$ hitung $=4,210>$ nilai $t$ tabel $=1,987$. Dengan demikian menunjukkan bahwa produk $\left(X_{1}\right)$ berpengaruh positif signifikan terhadap keputusan pembelian (Y). 
Hasil pengujian hipotesis menunjukkan bahwa nilai $t$ hitung untuk harga adalah 3,508 dengan signifikansinya sebesar $0,00 \mathrm{I}$; sedangkan pada taraf signifikansi sebesar 0,05 dengan degree of freedom $(\mathrm{df})$ sebesar $=89$ diperoleh nilai $t$ tabel sebesar 1,987 sehingga nilai $t$ hitung $=3,508>$ nilai $t$ tabel $=1,987$. Dengan demikian menunjukkan bahwa harga $\left(X_{2}\right)$ berpengaruh positif signifikan terhadap keputusan pembelian (Y).

Hasil pengujian hipotesis menunjukkan bahwa nilai $t$ hitung untuk pelayanan adalah I,829 dengan signifikansinya sebesar 0,054; sedangkan pada taraf signifikansi sebesar 0,05 dengan degree of freedom (df) sebesar $=89$ diperoleh nilai $t$ tabel sebesar I,987 sehingga nilai $\mathrm{t}$ hitung $=1,829<$ nilai $\mathrm{t}$ tabel $=1,987$. Dengan demikian menunjukkan bahwa pelayanan $\left(X_{3}\right)$ berpengaruh positif tidak signifikan terhadap keputusan pembelian $(Y)$.

Dengan demikian dapat disimpulkan bahwa produk dan harga secara parsial berpengaruh positif terhadap keputusan pembelian. Sedangkan pelayanan secara parsial berpengaruh positif tidak siginifikan terhadap keputusan pembelian.

2. Pengujian Hipotesis Secara Simultan (uji F)

Uji $F$ digunakan untuk mengetahui pengaruh produk $\left.X_{1}\right)$, harga $\left(X_{2}\right)$ dan pelayanan $\left(X_{3}\right)$ secara serempak (simultan) terhadap keputusan pembelian (Y).

\section{Tabel 5. Uji Hipotesis Secara Simultan} (Uji F)

\begin{tabular}{|c|c|c|c|c|c|c|}
\hline \multicolumn{7}{|c|}{ ANOVA ${ }^{x}$} \\
\hline & & $\begin{array}{l}\text { Damu } \\
\text { Scuares }\end{array}$ & at & PAean Square & 1 & S18. \\
\hline \multirow[t]{3}{*}{1} & liegressich & 45577 & 3 & $15177 \%$ & 4? 1 ?!9 & $.000^{2}$ \\
\hline & Renjudaal & 234.522 & 89 & $3.08:$ & & \\
\hline & Tulal & P9 49: & (1) & & & \\
\hline
\end{tabular}

b. I 'redictors: Constart, l :ekmanan, Harse, l iroduk

Sumber : Data primer diolah (2017)

Hasil perhitungan yang telah dilakukan diperoleh nilai $F$ hitung adalah sebesar 40,189 sedangkan degree of freedom ( $\mathrm{df}$ ) pada angka 3 dan 89 dalam tabel $F$ diperoleh nilai sebesar 2,707 sehingga nilai $F$ hitung sebesar $40,189>$ nilai $F$ tabel $=2,707$. Hal ini menunjukkan bahwa terdapat pengaruh signifikan secara serempak antara produk $\left(X_{1}\right)$, harga $\left(X_{2}\right)$ dan pelayanan $\left(X_{3}\right)$ terhadap keputusan pembelian $(Y)$.

\section{Pembahasan}

Berdasarkan pengujian secara simultan diketahui bahwa nilai $F$ hitung sebesar 49,189 dengan nilai signifikansi 0,000 dan dapat disimpulkan bahwa produk, harga dan pelayanan secara serempak berpengaruh signifikan terhadap keputusan pembelian pada PT. Jiwasraya Tangerang. Berdasarkan pengujian secara parsial diketahui pengaruh dari masingmasing variabel independen terhadap variabel dependen sebagai berikut :

\section{Pengaruh Produk terhadap Keputusan Pembelian}

Berdasarkan pengujian secara parsial diperoleh hasil bahwa variabel produk berpengaruh positif dan signifikan terhadap keputusan pembelian. Hal ini terlihat dari nilai signifikansinya lebih kecil dari 0,05 yaitu 0,000 dan nilai $t$ hitung lebih besar dari nilai $t$ tabel $(4,210>1,987)$.

Ini artinya PT. Jiwasraya adalah asuransi jiwa yang menawarkan produk-produk secara jelas dan terperinci, asuransi jiwa yang menawarkan variasi produk, asuransi yang memberikan manfaat yang jelas bagi konsumennya, asuransi yang memberikan kemudahan dalam proses memperoleh produk, dan proses pengklaiman pada produk PT. Jiwasraya mudah dan sesuai dengan apa yang dijanjikan.

\section{Pengaruh Harga terhadap Keputusan Pembelian}

Berdasarkan pengujian secara parsial diperoleh hasil bahwa variabel harga berpengaruh positif dan signifikan terhadap keputusan pembelian. Hal ini terlihat dari nilai signifikansinya lebih kecil dari 0,05 yaitu 0,00 I dan nilai t hitung lebih kecil dari t tabel (3,508 > I,987).

Ini artinya biaya iuran bulanan produk PT. Jiwasraya wajar dan terjangkau, biaya iuran bulanan produk yang dikeluarkan sebanding dengan keuntungan dan manfaat yang dihasilkan produk yang ditawarkan oleh PT. Jiwasraya, biaya-biaya operasional yang dibebankan oleh PT. Jiwasraya tergolong wajar dan terjangkau dan premi yang dibebankan oleh PT. Jiwasraya pada masing-masing produknya tergolong wajar dan terjangkau.

\section{Pengaruh Pelayanan terhadap Keputusan Pembelian}

Berdasarkan pengujian secara parsial diperoleh hasil bahwa variabel pelayanan positif dan tidak signifikan terhadap keputusan pembelian. Hal ini terlihat dari nilai signifikansinya lebih besar dari 0,05 yaitu 0,054 dan nilai $\mathrm{t}$ hitung lebih besar dari nilai $\mathrm{t}$ tabel $(\mathrm{I}, 829>\mathrm{I}, 990)$. 
Ini artinya pelayanan tidak mempengaruhi responden untuk membeli produk jasa PT. Asuransi Jiwasraya.

\section{PENUTUP}

\section{Kesimpulan}

Berdasarkan penelitian yang telah dilakukan maka dapat diperoleh kesimpulan sebagai berikut:

I. Hasil dari pengujian Statistik F menunjukkan bahwa variabel produk, harga dan pelayanan secara bersama-sama berpengaruh terhadap keputusan pembelian pada PT. Jiwasraya Tangerang.

2. Hasil dari pengujian Statistik t menunjukkan pengaruh variabel bebas terhadap variabel terikat secara individual (parsial) bahwa produk $\left(X_{1}\right)$ dan harga $\left(X_{2}\right)$ memiliki pengaruh positif dan signifikan keputusan pembelian pada PT. Jiwasraya Tangerang. Sedangkan variabel pelayanan $\left(X_{3}\right)$ berpengaruh secara positif dan tidak signifikan terhadap keputusan pembelian pada PT. Jiwasraya Tangerang.

3. Berdasarkan pengujian Koefisien Determinasi $\left(R^{2}\right)$ diketahui bahwa $R$ sebesar 0,790 berarti hubungan antara produk, harga, dan pelayanan terhadap keputusan pembelian $79,0 \%$. Hal ini berarti hubunganya cukup erat .Nilai Adjusted $R$ Square $=0,6 \mathrm{II}$ berarti $61,1 \%$ keputusan pembelian dapat dijelaskan oleh variabel variabel memahami produk, harga, dan pelayanan sedangkan sisanya $38,9 \%$ dijelaskan oleh faktor-faktor lain yang tidak diteliti dalam penelitian ini .

\section{Saran}

Berdasarkan hasil penelitian maka dapat diberikan saran-saran sebagai berikut:

I. PT. Jiwasraya Tangerang harus terus menawarkan produk yang bervariasi. Dan akan lebih baik apabila PT. Jiwasraya Tangerang juga menjelaskan lebih terperinci lagi setiap produk yang mereka tawarkan, agar konsumen dapat memahami secara lebih baik seluruh produk yang PT. Jiwasrya Tangerang tawarkan, dan tertarik untuk melakukan pembelian.

2. PT. Jiwasraya Tangerang harus terus mempertahankan harga yang sesuai dengan manfaat yang mereka berikan kepada para konsumen. Namun ada baiknya pula PT. Jiwasraya Tangerang memberikan penawaran-penawaran dengan harga yang menarik. Agar para konsumen terus melakukan pembelian di PT. Jiwasraya Tangerang.

3. PT. Jiwasraya Tangerang dituntut untuk memberikan pelayanan yang lebih baik lagi kepada konsumen, agar konsumen akan terus melakukann pembelian pada PT. jiwasraya Tangerang. Peningkatan pelayanan yang dapat ditingkatkan dengan kesopanan, keramahan, kesabaran, dan kecekatan dalam melayani konsumen.

4. Bagi peneliti selanjutnya, disarankan agar dapat menambahkan variabel independen dengan melihat faktor-faktor apa sajakah yang dapat mempengaruhi keputusan pembelian dan dapat menambahkan variabel lainnya seperti financial benefit, social benefit, promosidan ekuitas merek dII sehingga dapat memberikan hasil yang lebih baik lagi.

\section{DAFTAR PUSTAKA}

Dharmesta, B.S., dan T.H. Handoko. 2008. Manajemen Pemasaran: Analisis Perilaku Konsumen. Edisi Pertama Cetakan Keempat, Yogyakarta: BPFE.

Durianto. 20II. Invasi Pasar dengan Iklan yang Efektif. Jakarta: Gramedia Pustaka Utama.

Engel, James F. and R.D Blackwell and P.W Miniard. 2003. Perilaku Konsumen. Edisi Keenam. Jilid I. Jakarta: Binarupa Aksara.

Ghozali, Imam. 2005. Aplikasi Analisis Multivariate Dengan Program SPSS. Edisi Ketiga. Semarang: Badan Penerbit Universitas Diponegoro.

Hasan, Ali. 2008. Marketing. Yogyakarta: Media Utama.

Kasali, Renald. 2008. Membidik Pasar Indonesia. Jakarta: PT. Gramedia Pustaka Utama.

Kotler, Philip. 2008. Manajemen Pemasaran, Analisis, Perencanaan, Implementasi, dan Pengendalian. Alih bahasa Jaka Wasana. Jakarta: Erlangga.

Kotler, Philip. 2006. Manajemen Pemasaran, Edisi Pertama. Jakarta: PT. Indeks Kelompok Gramedia.

Lovelock, Wirtz. 20II. Services Marketing (People, Technology, Strategy). Pearson Education Limited. England.

Nurdiana. 2007. Pengaruh Positioning

Terhadap Keunggulan Bersaing dan Keputusan Pembelian SGM I PT 
Sari Husada Tbk (studi Kasus pada ADA Swalayan Cabang Siliwangi Semarang). Jurnal Administrasi Bisnis.

Priyatno, Dwi. 2009. 5 Jam Belajar Olah Data dengan SPSS 17. Yogyakarta: Andi.

Schiffman dan Kanuk. 2007. Consumer Behavior. New Jersey: Pearson Prestice Hall.

Sekaran, Uma. 2003. Metodologi Penelitian Untuk Bisnis. Jakarta: Salemba Empat.

Soegoto, Eddy Soeryanto. 2009. Enterpreneurship, Edisi Pertama. Jakarta: PT. ElekMedia Komputindo.

Sugiyono. 2006. Metode Penelitian Bisnis. Alfabeta: Bandung.

Utami, Christina Widhya. 2010. Manajemen Ritel. Jakarta: Salemba Empat. 